Acta Theriologica, Suppl. 5: 179-186, 1998.

PL ISSN 0001-7051

\title{
Influence of selection and management on the genetic structure of reindeer populations
}

\author{
Knut H. RøED
}

Røed K. H. 1998. Influence of selection and management on the genetic structure of reindeer populations. [In: Ecological genetics in mammals III. G. B. Hartl and J. Markowski, eds]. Acta Theriologica, Suppl. 5: 179-186.

Polyacrylamide gel electrophoresis was used to analyse transferrin variation in semi-domestic and wild populations of reindeer Rangifer tarandus (Linnaeus, 1758) in Norway. The transferrin allele frequencies were compared with those previously reported for semi-domestic and wild populations in Fennoscandia. Altogether 2531 specimens from 20 semi-domestic and six wild populations were analysed. In all populations the heterozygosity was high, with a mean of 0.75 for both semi-domestic and wild populations. The pattern of allele frequency distribution indicated a particularly high genetic distance between semi-domestic and wild populations. The high genetic distance was mainly due to a different pattern in the distribution of the two most common transferrin alleles, $T f^{C 1}$ and $T f^{E 1}$. The average ratio between the frequency of $T f^{C 1}$ and $T f^{E 1}$ was on the average three times greater in semi-domestic as compared to wild populations. The sorting of populations analysed according to the $T f^{C 1} / T f^{E 1}$-ratio revealed that all wild populations showed a lower ratio than all semi-domestic populations. This difference in allele frequency distribution is discussed in relation to possible different origins of semi-domestic and wild reindeer in Fennoscandia or, alternatively, to the possible existence of different selection forces acting at the transferrin locus in wild and semi-domestic reindeer.

Department of Morphology, Genetics and Aquatic Biology, Norwegian College of Veterinary Medicine, P. O. Box 8146 Dep., N-0033 Oslo 1, Norway

Key words: Rangifer tarandus, genetic differentiation, transferrin, selection, management

\section{Introduction}

Different strategies for the management of animal populations can alter the extant selection regimes and, thus, affect the genetic composition of a population. The reindeer Rangifer tarandus (Linnaeus, 1758) exists in considerable numbers both as wild and semi-domestic animals and is therefore well suited for studies on genetic effects of different management strategies. In Europe, the main wild reindeer populations are found in central Norway while the semi-domestic herds are almost continuously distributed over both central and northern Fennoscandia and northern Russia. The semi-domestic animals are mainly free-ranging and spend most of their lives under the same natural conditions as the wild animals. However, in both semi-domestic and wild animals, population size and structure are almost completely controlled by man; in the case of semi-domestic animals by selective breeding, mainly aimed at increased meat production, and in the case of 
wild reindeer by hunting, which usually constitutes the most important mortality factor (Reimers et al. 1980).

One approach to the study of genetic effects of different management strategies is to investigate the frequency distribution of alleles at polymorphic loci. In reindeer the serum transferrin locus has proved to be very useful for genetic studies because it shows a high degree of allelic variation (Gahne and Rendel 1961, Brænd 1964, Zhurkevich and Fomicheva 1976, Shubin 1977, Shubin and Ionova 1984, Røed 1985, Røed et al. 1991). The main pattern of variability reported in these studies indicates considerable genetic heterogeneity at the transferrin locus among populations of reindeer and caribou. A particularly high degree of differentiation has been reported to exist between populations of semi-domestic and wild reindeer, both in Eurasia (Brænd 1964, Shubin and Ionova 1981, Røed 1985, Røed et al. 1987) and in Alaska (Røed and Whitten 1986).

In the present paper differences in transferrin allele frequencies among populations of semi-domestic and wild reindeer in Fennoscandia are presented and discussed in relation to possible different origins of semi-domestic and wild reindeer in Fennoscandia and, alternatively, to the possible action of different selective forces due to management practices in semi-domestic and wild reindeer.

\section{Material and methods}

Serum or plasma samples were obtained from three semi-domestic herds (Vågå, Brurskanken and Lom) and from two wild populations (Rondane and Knutshø). Samples were also taken from a population named Rendalen, which originates from 120 semi-domestic reindeer (100 females and 20 bucks) introduced into the area about seventy years ago and since then harvested by hunting (Brænd 1964). The samples were subjected to vertical slab polyacrylamide gel electrophoresis as described by Røed (1985). The transferrins were visualized by overnight staining with Coomassie Brilliant Blue (Diezel et al. 1972). Transferrin allele frequencies were compared with estimates previously reported for both wild and semi-domestic reindeer in Fennoscandia (Røed et al. 1987). Altogether 2531 samples, representing 26 different populations, were analysed. The respective geographic location of each of these populations is given in Fig. 1. All reindeer belong to the subspecies Eurasian tundra reindeer $(R$. $t$. tarandus). The coefficient of genetic distance between populations was calculated according to Nei (1972).

\section{Results}

Table 1 presents the transferrin allele frequencies in the populations sampled for the present study together with frequencies in populations included for comparison. The values for the wild Knutshø population are pooled from data obtained in the present study and those previously reported in Røed et al. (1987). Table 2 shows the degree of genetic variation at the transferrin locus for each population in terms of the number of alleles scored and of expected heterozygosities calculated from observed allele frequencies. In all populations the number of alleles was high, ranging from seven to eleven, with a mean value of heterozygosity of 0.75 . The average heterozygosity was the same for semi-domestic and wild populations. 


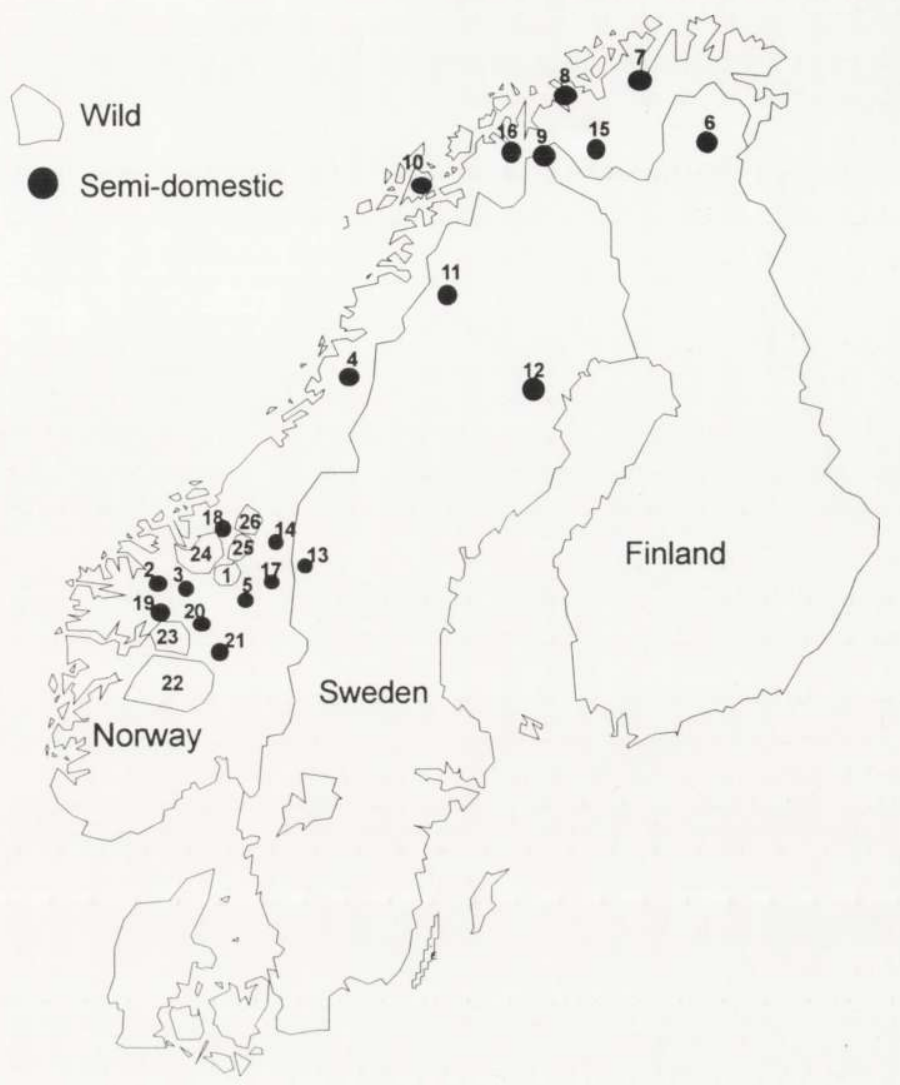

Fig. 1. Geographic location of the sampled populations of semi-domestic and wild reindeer in Fennoscandia.

The mean genetic distance was 0.06 among semi-domestic herds and 0.12 among wild populations. The greatest genetic distance was definitely between semi-domestic and wild populations, ranging from 0.02 to 0.86 , with a mean of 0.22 (Table 3 ).

The great difference in transferrin allele frequency distribution between semi-domestic and wild populations was mainly due to a different pattern in the distribution of the two most common alleles in semi-domestic and wild populations (Table 4): $T f^{C 1}$ was more frequently distributed among semi-domestic herds than among wild populations, while $T f^{E 1}$ was more frequently distributed among wild populations than among semi-domestic herds. This difference between semi-domestic and wild populations is further illustrated by the average ratio between the frequency of $T f^{C 1}$ and $T f^{E 1}$. This ratio was on the average three times greater in semi-domestic than in wild populations (Table 4). A sorting of all populations analysed according to this ratio reveals that all wild populations showed a lower ratio than all the semi-domestic herds (Table 5). 


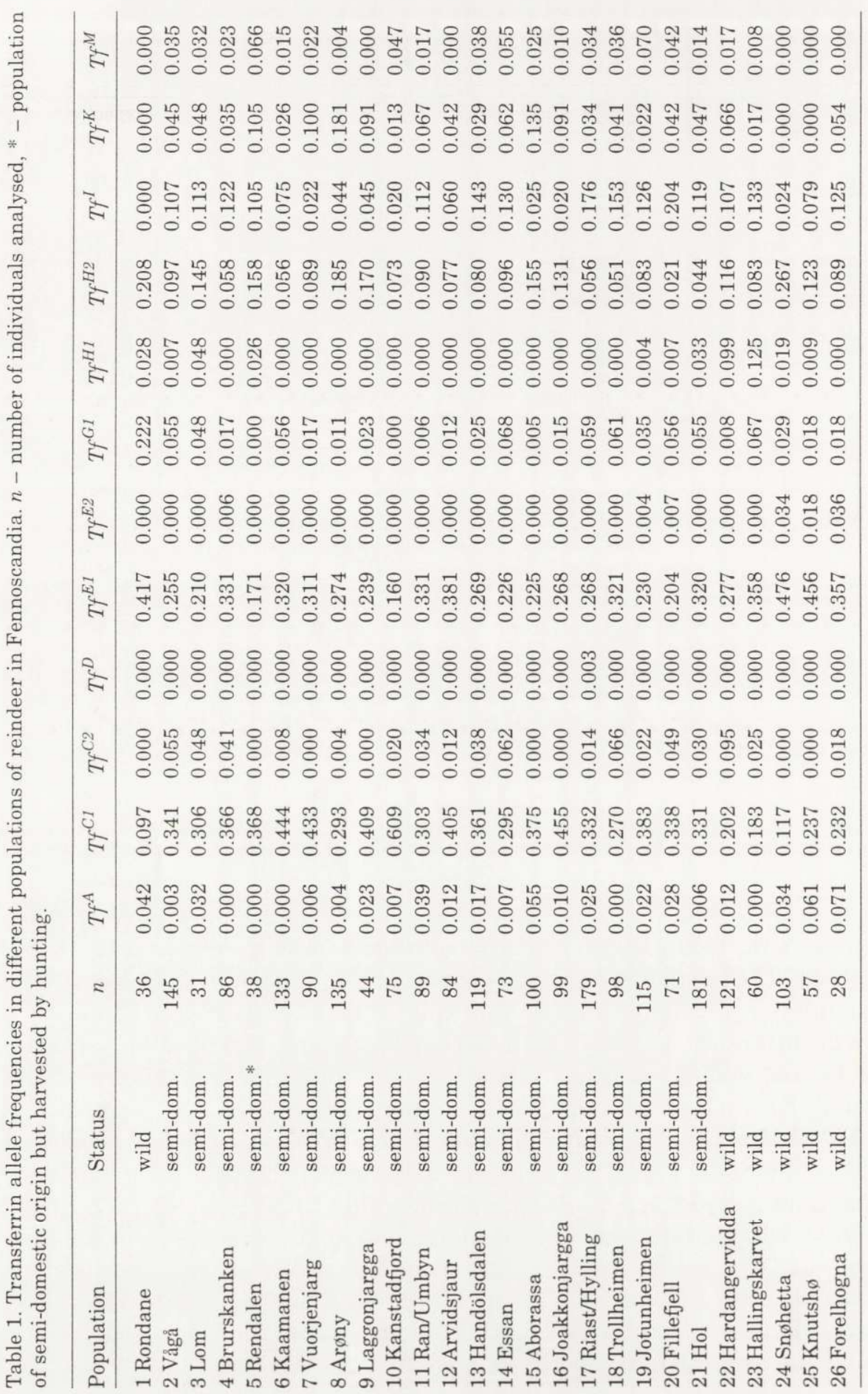


Table 2. Level of genetic variability at the transferrin locus in Fennoscandian semi-domestic and wild reindeer populations. ${ }^{*}$ - population of semi-domestic origin but harvested by hunting.

\begin{tabular}{llcc}
\hline Population & Status & Number of alleles & $\begin{array}{c}\text { Expected } \\
\text { heterozygosity }\end{array}$ \\
\hline 1 Rondane & wild & 6 & 0.721 \\
2 Vågå & semi-dom. & 10 & 0.789 \\
3 Lom & semi-dom. & 10 & 0.817 \\
4 Brurskanken & semi-dom. & 9 & 0.735 \\
5 Rendalen & semi-dom.* & 6 & 0.783 \\
6 Kaamanen & semi-dom. & 8 & 0.691 \\
7 Vuorjenjarg & semi-dom. & 8 & 0.700 \\
8 Arøny & semi-dom. & 9 & 0.773 \\
9 Laggonjargga & semi-dom. & 7 & 0.744 \\
10 Kanstadfjord & semi-dom. & 8 & 0.602 \\
11 Ran/Umbyn & semi-dom. & 9 & 0.774 \\
12 Arvidsjaur & semi-dom. & 8 & 0.683 \\
13 Handölsdalen & semi-dom. & 9 & 0.769 \\
14 Essan & semi-dom. & 9 & 0.826 \\
15 Aborassa & semi-dom. & 8 & 0.766 \\
16 Joakkonjargga & semi-dom. & 8 & 0.699 \\
17 Riast/Hylling & semi-dom. & 10 & 0.779 \\
18 Trollheimen & semi-dom. & 8 & 0.790 \\
19 Jotunheimen & semi-dom. & 11 & 0.774 \\
20 Fillefjell & semi-dom. & 11 & 0.797 \\
21 Hol & semi-dom. & 10 & 0.766 \\
22 Hardangervidda & wild & 10 & 0.837 \\
23 Hallingskarvet & wild & 9 & 0.799 \\
24 Snøhetta & wild & 8 & 0.688 \\
25 Knutshø & wild & 7 & 0.710 \\
26 Forelhogna & wild & 9 & 0.799 \\
\hline
\end{tabular}

Table 3. Average genetic distance (with range) at the transferrin locus between populations of semi-domestic and wild reindeer in Fennoscandia.

\begin{tabular}{lcc}
\hline Population & Semi-domestic & Wild \\
\hline Semi-domestic & $0.06(0.01-0.26)$ & \\
Wild & $0.22(0.02-0.86)$ & $0.12(0.02-0.27)$ \\
\hline
\end{tabular}

Table 4. Mean values $( \pm \mathrm{SE})$ for frequencies of $T f^{C 1}$ and $T f^{E 1}$, and the ratio between these values in populations of semi-domestic and wild reindeer in Fennoscandia.

\begin{tabular}{lccc}
\hline Population & $T f^{C 1}$ & $T f^{E 1}$ & $T f^{C 1} / T f^{E 1}$ \\
\hline Semi-domestic & $0.37(0.02)$ & $0.27(0.01)$ & $1.50(0.14)$ \\
Wild & $0.18(0.02)$ & $0.39(0.03)$ & $0.48(0.08)$ \\
\hline
\end{tabular}


Table 5. Ratio between the frequencies of $T f^{C 1}$ and $T f^{E 1}$ in semi-domestic and wild populations of reindeer in Fennoscandia. The populations are listed in decreasing order of $T f^{C 1} / T f^{E 1}$.* - population of semi-domestic origin but harvested by hunting.

\begin{tabular}{|c|c|c|}
\hline Population & Status & $T f^{C 1} / T f^{E 1}$ \\
\hline 10 Kanstadfjord & semi-dom. & 3.81 \\
\hline 5 Rendalen & semi-dom.* & 2.15 \\
\hline 9 Laggonjargga & semi-dom. & 1.71 \\
\hline 16 Joakkonjargga & semi-dom. & 1.70 \\
\hline 15 Aborassa & semi-dom. & 1.67 \\
\hline 19 Jotunheimen & semi-dom. & 1.67 \\
\hline 20 Fillefjell & semi-dom. & 1.66 \\
\hline 3 Lom & semi-dom. & 1.46 \\
\hline 7 Vuorjenjarg & semi-dom. & 1.39 \\
\hline 6 Kaamanen & semi-dom. & 1.38 \\
\hline 13 Handölsdalen & semi-dom. & 1.34 \\
\hline 2 Vågå & semi-dom. & 1.34 \\
\hline 14 Essan & semi-dom. & 1.31 \\
\hline 17 Riast/Hylling & semi-dom. & 1.24 \\
\hline 8 Arnøy & semi-dom. & 1.10 \\
\hline 12 Arvidsjaur & semi-dom. & 1.07 \\
\hline $21 \mathrm{Hol}$ & semi-dom. & 1.03 \\
\hline 4 Brurskanken & semi-dom. & 1.02 \\
\hline $11 \mathrm{Ran} / \mathrm{Umbyn}$ & semi-dom. & 0.92 \\
\hline 18 Trollheimen & semi-dom. & 0.84 \\
\hline 22 Hardangervidda & wild & 0.73 \\
\hline 26 Forelhogna & wild & 0.65 \\
\hline 25 Knutsh & wild & 0.52 \\
\hline 23 Hallingskarvet & wild & 0.51 \\
\hline 24 Snøhetta & wild & 0.25 \\
\hline 1 Rondane & wild & 0.23 \\
\hline
\end{tabular}

\section{Discussion}

The transferrin allele frequency distribution in reindeer of Fennoscandia provides convincing evidence of considerable genetic differentiation between semi-domestic herds on the one hand and wild populations on the other. The large amount of variation in all populations analysed suggests that recent genetic drift or a founder effect had not been the principal factor governing this genetic differentiation. It rather suggests that semi-domestic and wild reindeer have different geographic origins or that different selection forces are, or had been acting upon genotyps at the transferrin locus in these animals.

Different origins of wild and semi-domestic reindeer in Norway may be theresult of an immigration of wild reindeer to Fennoscandia from the south after the last glaciation period, and an immigration of ancestors of the present semi-donestic reindeer from the east. There is evidence that reindeer were present south of the 
glacier covering most of northern Eurasia during the last glaciation period (Banfield 1961). Reindeer could thus have colonised the land from south to north as the ice retreated and have become ancestors of the present wild reindeer in Fennoscandia. On the other hand, the domestication of reindeer could have originated among reindeer in northern Eurasia, which were descendants of reindeer having survived the glaciation period in the Beringia refugium in Siberia/Alaska. As the ice retreated, these reindeer could have colonised Eurasia from east to west.

According to the taxonomic study of Banfield (1961), subspecies of reindeer and caribou should be divided into two groups: the tundra reindeer/caribou (Cyclocornis) and the forest or woodland reindeer/caribou (Compressicornis). The continental tundra form should have originated in the Beringia refugium and the woodland caribou form in temperate refugia south of the continental ice sheets. That tundra and woodland caribou in North America are of different origin is also supported by transferrin variability: Several alleles are present in woodland caribou and not in tundra caribou, and vice versa (Røed et al. 1991). The genetic distance between tundra and woodland caribou in continental Canada was 0.94 (cf Røed et al. 1991), which is much higher than the genetic distance value reported here between wild and semi-domestic reindeer in Fennoscandia. If wild and semi-domestic reindeer in Fennoscandia had different ancestors, which survived the glaciation period in different refugia, one would expect a much greater genetic distance to have emerged through time. In addition, genetic similarity at the transferrin locus was found to be greater between Alaska caribou and Norwegian wild reindeer than between Alaska caribou and Norwegian semi-domestic reindeer (Røed and Whitten 1986). It therefore appears that wild and semi-domestic reindeer in Fennoscandia have common ancestors, which probably originated from the Beringia refugium.

Previously reported associations between body weight and transferrin alleles in reindeer (Røed 1987) may support the hypothesis that selection has been an important factor in determining the allele frequency difference between semidomestic and wild reindeer. A positive association between $T f^{C 1}$ and high body weight among male calves was reported by Røed (1987). An increase in the frequency of $T f^{C 1}$ and a decrease in the frequency of $T f^{E 1}$ associated with selection for calf body weight in a semi-domestic herd was reported by Røed (1985). Increased calf body weight could thus contribute to the generally higher frequency of $T f^{C 1}$ and the lower frequency of $T f^{E 1}$ seen in semi-domestic as compared to wild populations. The possibility that the divergence between wild and semi-domestic populations can be explained by selective forces acting on wild reindeer should also be considered. Harvest through the regular hunt is the most important mortality factor in Norwegian wild reindeer (Reimers et al. 1980). In an open habitat, the hunter is able to classify and select single specimens living in flocks, such as the reindeer. Skogland (1989) has suggested that size-specific hunt predation is responsible for a change in the mean body weight of females in a Norwegian wild population. This effect was found to have taken place over a hunting period of seventeen years. However, the allele frequencies in the Rendalen 
population, which originates from semi-domestic animals and which has been hunted during most of this century, show a typical semi-domestic pattern with a relatively high $T f^{C 1} / T f^{E 1}$ frequency ratio (Table 5). This population was analysed for transferrin variation also about thirty years ago (Brænd 1964). Also back then the allele frequencies showed a typical semi-domestic pattern with a relatively high $T f^{C 1} / T f^{E 1}$-ratio (1.72). The $T f^{C 1} / T f^{E 1}$-ratio of 2.15 presently found in this population indicates that no reduction has taken place over the last thirty years. A reduced ratio would be expected if the hunting practice had acted as a selective force on transferrin genotypes in reindeer. The alternative hypothesis that reindeer husbandry acts a a selective force is therefore a more reasonable explanation of the high genetic divergence at the transferrin locus between semi-domestic and wild populations in Fennoscandia.

\section{References}

Banfield A. W. F. 1961. A revision of the reindeer and caribou, genus Rangifer. National Museum of Canada, Bulletin No. 177, Biological Series No. 66.

Brænd M. 1964. Genetic studies on serum transferrin in reindeer. Hereditas 52: 181-188.

Diezel W., Kopperschlager G. and Hoffmann E. 1972. An improved procedure for protein staining in polyacrylamide gels with a new type of Coomassie Brilliant Blue. Analytical Biochemistry 48: 617-620.

Gahne B. and Rendel J. 1961. Blood and serum groups in reindeer compared with those in cattle. Nature 129: 529-530.

Nei M. 1972. Genetic distance between populations. American Naturalist 106: 283-292.

Reimers E., Villmo L., Gaare E., Holthe V. and Skogland T. 1980. Status of Rangifer in Norway including Svalbard. [In: Proc. 2nd Int. Reindeer/Caribou Symp., Røros, Norway 1979. E. Reimers, E. Gaare and S. Skjenneberg, eds]. Direktoratet for vilt og ferskvannsfisk, Trondheim, Norway: 774-785.

Røed K. H. 1985. Genetic differences a the transferrin locus in Norwegian semi-domestic and wild reindeer (Rangifer tarandus L.). Hereditas 102: 199-206.

Røed K. H. 1987. Transferrin variation and body size in reindeer, Rangifer tarandus L. Hereditas 106: 67-71.

Røed K. H., Ferguson M. A. D., Crête M. and Bergerud T. A. 1991. Genetic variation in transferrin as a predictor for differentiation and evolution of caribou from eastern Canada. Rangifer 11: 65-74.

Røed K. H. and Whitten K. R. 1986. Transferrin variation and evolution of Alaska reindeer and caribou, Rangifer tarandus L. Rangifer, Special Issue No 1: 247-251.

Røed K. H., Mossing T., Nieminen M. and Rydberg A. 1987. Transferrin variation and genetic structure of reindeer populations in Scandinavia. Rangifer 7: 12-21.

Shubin P. N. 1977. Electrophoretic study of proteins in two races of reindeer. Izviestia Akademii Nauk SSSR, Ser. Biol. 6: 819-828. [In Russian with English summary]

Shubin P. N. and Ionova T. A. 1984. Genetic interrelation between the domestic and wild reindeer (Rangifer tarandus). Zoologichskii Zhurnal 63: 1725-1731. [In Russian with English summary]

Skogland T. 1989. Natural selection of wild reindeer life history traits by food limitation and predation. Oikos 55: 101-110.

Zhurkevich N. M. and Fomicheva I. I. 1976. Genetic polymorphism of transferrin of blood serum in reindeer (Rangifer tarandus L.) indigenous to northeastern Siberia. Genetika 12: 56-65. [In Russian with English summary]

Received 23 March 1998, accepted 30 April 1998. 